\title{
Problems and Countermeasures about Social Capital's Participating in Water Pollution Control PPP Project
}

\author{
Yong Ma, Qingjun Meng, Yuting Liu \\ Business School, Hohai University, Nanjing, China \\ Email: 595930926@qq.com
}

Received 29 July 2016; accepted 21 August 2016; published 24 August 2016

Copyright (C) 2016 by authors and Scientific Research Publishing Inc.

This work is licensed under the Creative Commons Attribution International License (CC BY).

http://creativecommons.org/licenses/by/4.0/

cc) (i) Open Access

\begin{abstract}
In order to improve the quality and efficiency of water pollution prevention and control project, the State encouraged social capital to participate in water pollution prevention and control PPP projects. But there are some problems in the field, including a low rate of return on investment, the imperfect investment environment and so on which hinder the participation of social capital in these PPP projects. So we need to perfect the social capital investment return mechanism, and establish a fair and safe investment environment and take other measures.
\end{abstract}

Keywords

Water Pollution Prevention, PPP, Social Capital, Public Products

\section{Introduction}

Strengthening water pollution prevention and control efforts to protect the national water safety is related to national economy and people's livelihood and is the focus of environmental protection work. At present, in the field of water pollution prevention and control, integrated watershed management, safe drinking water, environmental monitoring and other environmental public goods and services are primarily invested by government and the investment ability of government is limited. With the development of economy and the life of people gradually improved, some achievements have been made in the prevention and control of water pollution, but have not met the requirements of society. On the premise that the Central Government or various levels of government funding are limited, guiding social capital into the field actively is particularly urgent. Only relaying on the special funds invested by the Central Government to "water-control" is not enough. On the basis that Central Government puts 13 billion yuan of special funds into the water pollution prevention and control, and guides social capital to participate in the "water-control", the water ecological security objectives will be achieved. Dur- 
ing the process, the PPP project will play an important role [1].

The Ministry of Finance and the Ministry of Environmental Protection jointly issued the "opinions on promoting the cooperation between the government and the social capital in the field of water pollution prevention and control" ("opinions"), to promote the use of cooperation between the Government and social capital (PPP) Models in the areas of water pollution prevention and control which has a significant meaning in improving the quality of the supply of environmental public products and services, enhancing the capability and efficiency of water pollution prevention and control. Not only that, this is the important content of the next phase of economic restructuring, improving the quality of economic growth and even the field of water pollution prevention and control will become a new economic growth point. At present, there are some problems in this field, including a low rate of return on investment, long payback period, the imperfect investment environment and incomplete mechanism to guide the social capital's investment. These problems caused the low enthusiasm and initiative of social capital in the field of water pollution prevention and control. It is still a problem to attract social capital. Therefore, this paper aims to find the fundamental causes through the facts analysis of hindering the social capital's entrance to the water pollution control PPP project, and combined with the actual situation of our country, puts forward more countermeasures to attract social capital.

\section{Factors Preventing Social Capital to Participate in Water Pollution Control PPP Project}

\subsection{Low Rate of Return on Investment of PPP Projects}

In the PPP projects, the Government's main purpose is the provision of public goods or services. But for the for-profit social capital, their investment in the construction or operation of PPP projects is a kind of investment behavior and is essentially the same with other financial investment activities such as buying securities and stocks. Both of them are in order to obtain a reasonable return. Government and social capital fail to reach an agreement on return on investment had led to failures of many PPP projects which told us the return on investment is an important factor that affect the social capital's involvement in PPP projects. So the government should have a standard for the rate of return on different types of PPP projects. Some experts believe that for the "user charges" PPP projects, reasonable rate of return on investment at this stage can be set at about 7.0\% - 8.0\% and these projects paid by the Government should be set at about 5.0\% - 6.0\% [2]. However, most of the water pollution prevention and control projects have a strong public interest and externalities, little or no cash flow and a long recovery cycle. These characteristics determine the sustainable and stable fund is difficult to obtain in a short time and the rate of return is generally low. It is difficult for social capital to accept it.

\subsection{Long Payback Period of Investment of PPP Projects}

An important feature of the PPP project is the large investment scale and long payback period of investment. Most projects can be recycled for a short period of 10 years, and it will take 30 years even a longer period to recover the investment. The Long payback period means that a large amount of social capital should be occupied by the project for a long time, it cannot carry out other investment activities, and the investment cannot be fully utilized by social capital to obtain the maximum benefits.

Not only that, the long period of investment still affects the enthusiasm of social capital to participate in the water pollution control PPP project. A Longer investment cycle makes an enhanced possibility of law, politics and other risks. For example, the current legal system of the PPP in our nation is not perfect, and it is bound to carry out some amendments and adjustments in law, with continuous development of the PPP model. And this may lead to the changes in project's legitimacy, market demand, products/service charges and so on. The negative impacts of normal constructions and operation in the project even lead to a failure of project. Except that, today's domestic and international economic downturn and the unhealthy and unstable of economic development may occur in a larger fluctuations in a certain period, which leads to the risks of interest rate, exchange rate and other financial risks, and this will affect the success of the PPP project. Therefore, a long payback period of investment is also a major reason for the lack of investment enthusiasm of social capital.

\subsection{Incomplete Investment Environment of PPP Projects}

Incomplete investment environment is mainly reflected in two aspects: one is high risk of the investment process 
and immature risk prevention and supervision mechanism; the second is the existence of barriers to financing. PPP projects have long and complex construction period. There are many kinds of risk in the period, including political risk, economic risk, legal risk, and so on. For example, a lot of existing laws have contradictions with the introduction of management of social capital. Because of the imperfect risk prevention mechanism, the social capital has to make a prudent choice before getting into the field. Existing supervision mechanisms are also not perfect. Project cannot be supervised effectively and the process of accountability confirmation is difficult. The governments have advantages in the cooperation relationships, and it's also what the social capital concerns.

In addition, the performance evaluation mechanism is flawed and there is not enough public information. Both of them are the reasons why the investment environment isn't safe and fair. PPP projects require a large capital. In 2015, the National Development and Reform Commission announced the total investment of 280 environmental protection PPP projects is 106.88 billion yuan and the environmental protection PPP projects have an average investment of 0.38 billion yuan. So the social capital often need to financing for the project, but PPP projects of water pollution prevention and control have the low rates of return, long recovery period, high risk which make the financing more difficult. It is not conducive to the entry of social capital.

\subsection{Imperfect Financial Guidance Mechanism}

As far as the implementation of PPP model in the field of water pollution prevention and control, except the mature operation models in the municipal sewage treatment project and are widely used at the local level, there is no successful experience to draw on for most of other kinds of projects, due to the lack of profit-making mechanism, despite the effort that some areas try to begin the groping work. In order to guide the implementation of PPP projects in the field of water pollution prevention and control and in other weak fields, we need to play the guiding role of fiscal expenditure policies and especially strengthen the incentive function of the central government environmental protection special fund to encourage local government to attempt boldly and innovatively, create bright spot, lead the demonstrations, set up benchmarks. Traditionally, most of china's fiscal expenditure is spent on the fixed-asset investment of early construction phases of projects and little money was used to support the operation and maintenance, which cannot guarantee to provide enough funds to advance the development of PPP models in the field of water pollution prevention and control and ensure the capital input in operation and maintenance that help projects play the environmental benefits. Traditional financial subsidy lays emphasis on the subsidy in the early stage. The subsidy fund is generally used for projects under construction or not built yet. It is hard to predicate the follow-up effect after use of funds. Furthermore, the phenomenon of embezzlement of funds also could take place [3]. Because of the public interest and externalities of projects in the field of water pollution prevention and control, the cost of PPP projects is paid by governments. The social capital has a single profit pattern which increases the risk of social capital and the financial pressure on the government.

\section{Countermeasures to Attract Social Capital to Participate in the PPP Project of Water Pollution Prevention and Control}

\subsection{Improve the Social Capital Investment Return Mechanism}

It's the basic premise to conduct government and social capital cooperation for the establishment of investment return mechanism. Based on comprehensively adopting the user charges, government subsidies and government pay, the "opinion" puts forward to encourage the innovation of bundling, resource portfolio development and other profit models according to the characteristics of environmental protection project [4]. As for the project that has a strong public interest but has an external benefit, it can be combined and developed with the supporting project resources in strong revenue creation ability, such as land development, water supply, under-forest economy, ecological agriculture, ecological fishery and ecological tourism, which are related with water pollution control. Meanwhile, the opinion encourages the effective integration of projects to implement "integrated water supply and drainage system, as well as factory network" between the urban and rural. Through the large scale business, it proposes to reduce construction and operating costs, enhance the overall profitability, expand external benefit and attract social capital to participate in [5].

The price formation mechanism in municipal solid waste disposal, sewage treatment and other water pollution prevention and control areas should be improved as soon as possible. Charging standard dynamic adjustment mechanism should be established based on the principle of ensuring reasonable income, so as to optimize gov- 
ernment subsidy system. Such as Guangzhou Xi Lang sewage treatment project, the payment and subsidy mechanism of the project is that the government provides the project company with sewage, the project company provides government with sewage treatment services that meet the contract requirements or water quality standards set by the environmental protection department. The government accepts the treated sewage and pays service fees to the cooperation company. Because the project is the country's first commercial sewage treatment project, it not only has no market price to refer, but also can't determine the normal social costs. Therefore, the project company and the government determine the price of services rationally in accordance with the project construction and operating costs, a reasonable profit and other factors, so as to enable the cooperative company to recover the project cost and obtain a reasonable profit through charging service fees under normal operating conditions.

\subsection{Establish a Fair and Safe Investment Environment}

"Opinion" emphasizes to establish a fair, open and transparent market environment, maintain the basic role of market mechanism. Local financial departments at all levels should coordinate the use of water pollution prevention and other related funds, optimize and adjust the use direction, expand the source of funding channels, provide appropriate preferential policies for PPP projects. Meanwhile, the "opinion" also requires financial and environmental protection department to establish an independent, transparent, accountable and professional PPP project supervision system, realize information disclosure, encourage public participation and accept public supervision; establish a comprehensive evaluation system for government and service users to participate in, promote the third party performance evaluation, form the evaluation result application mechanism and project post evaluation mechanism [6].

Experience shows that the important reason for government and social capital difficult to reach cooperation willingness is that social capital is unwilling to bear the payment risk caused by the unequal right between government credibility and the subject of contract. In order to eliminate the concerns of social capital, "opinion" puts forward to improve the payment mechanism, and encourages to adopt the third party payment system. However, current fiscal expenditure system is paid directly by the government financial system whether buying products or services. Intervention of the third party intermediary organization is conducive to establish a standardized, stable, normal payment system, and can mobilize the enthusiasm of social capital to enter the water pollution control field, as well as improving the efficiency of fiscal expenditure. So we need to speed up improving the process of consulting intermediary market [7].

In order to strengthen the financing capacity of PPP projects, projects can also get financing support by innovating financial products and services in addition to the government special funds supply. Specify contents include establishing the normal channels to promote PPP project to financial institutions, encouraging financial institutions to increase the credit line and enhance credit rating for related projects, so as to enhance the financing ability of PPP projects; supporting to develop pledge guarantee financing for incomes in emission rights, charging rights, government purchase service agreement and concession agreement, so as to enhance the financing guarantee ability of PPP projects; encouraging social capital to establish environmental protection funds, focusing on supporting the PPP projects in water pollution control [8].

\subsection{Optimize the Financial Guide System}

Firstly, it is necessary to strengthen the guiding function of special fund, which is one of main forms of the environmental protection expenditure of Central Treasury. During the period of "12th Five-year Plan", the special fund of Central Treasury for environmental protection was 180 billion Yuan approximately, accounting for about $62 \%$ of the environmental protection expenditure of Central Treasury. Judging from the environmental protection expenditure of Central Treasury, the special fund features large amount and strong guiding function. It also could play the role of wind indicator in environmental protection input of the local government. In a bid to motivate local government to implement water pollution control PPP model, the guiding function of special fund can be further intensified to encourage bringing into the regions supporting related funds including dynamic director of national key rivers and lakes or water pollution control special fund so as to take the lead in carrying forward PPP model.

Secondly, it is necessary to optimize financial support project link so that the local government takes advantage of special fund to support water pollution control and implement PPP model. The use of special fund should 
be gradually transformed into "operation reinforcement" from "construction reinforcement" to guide overall balanced development of water pollution control infrastructure construction and PPP model operation and maintenance.

Thirdly, it is necessary to improve the use pattern of financial fund. The post-award plays a significant role in promoting the supply quality of environmental public goods and services, so the governmental special fund subsidy mode of water pollution control PPP model should be gradually transformed into "post-award" from "presubsidy". Except investment subsidy and financial incentive, financing expense subsidy and governmental payment are also common financial fund support modes.

Ultimately, it is necessary to make innovation in viability gap subsidy mode. The possibility can be provided for combined development model including authorizing development and operation right, factory and network integration and industrial packaging through comprehensive utilization of one or many of policies including land assignment, income allowance, price subsidy, project contribution, transferring of return on equity and tax preference to facilitate building of proper public welfare profit mechanism for water pollution control project and promote the implementation of water pollution control PPP in wider field [9].

\section{Conclusion}

In China, the PPP model in water pollution prevention and control is still in the initial stage of exploration. And because of the lack of perfect institutional environment and investment environment, it cannot produce enough attraction to social capital. Therefore, it is necessary to promote the optimization process of a series of system and management to attract the participation of social capital. Then the water pollution prevention and control PPP projects can get better and more construction and operation.

\section{Acknowledgements}

This work was supported by National Social Science Foundation (20155020811).

\section{References}

[1] (2015) Governments Unite Social Capital to Widen Financing Channels for Water-Control. China Reform News, 18 May.

[2] Wu, Y.P. (2016) Set the Rate of Return on Investment of PPP Projects Scientifically. China Investment, 6, 76-77.

[3] (2015) Water Pollution Prevention and Control PPP Should Play the Guide Role of Financial Investment. China Environment News, 21 May.

[4] (2015) Advance PPP in the Field of Water Pollution Prevention and Control. China Business Times, 7 May.

[5] (2015) Social Capital Can Enter and Make Money. Economic Daily, 7 May.

[6] (2015) Water Pollution Prevention and Treatment PPP Will Be Fully “Opened”. China Economic News, 28 April.

[7] (2015) Implementation of PPP Model Is a New Way to Prevent and Treat the Pollution of Water. China Environment News, 13 May.

[8] (2015) The PPP Model of Water Pollution Prevention and Treatment Can Be Implemented "without Three Worry". China Information News, 27 May.

[9] Zhang, H.M. (2015) How to Make Good Use of PPP Model in the Field of Water Pollution Prevention and Treatment. Resources Inhabitant and Environment, 9, 31-33. 


\section{Submit or recommend next manuscript to SCIRP and we will provide best service for you:}

Accepting pre-submission inquiries through Email, Facebook, LinkedIn, Twitter, etc.

A wide selection of journals (inclusive of 9 subjects, more than 200 journals)

Providing 24-hour high-quality service

User-friendly online submission system

Fair and swift peer-review system

Efficient typesetting and proofreading procedure

Display of the result of downloads and visits, as well as the number of cited articles

Maximum dissemination of your research work

Submit your manuscript at: http://papersubmission.scirp.org/ 